\title{
JURNAL MAGISTER MANAJEMEN

\section{PENGARUH MOTIVASI TERHADAP PRODUKTIVITAS DENGAN KEPUASAN KERJA SEBAGAI VARIABEL INTERVENING PADA PEGAWAI NEGERI SIPIL DALAM KOORDINASI ASISTEN III KABUPATEN LOMBOK TIMUR}

\author{
Karyagus Sugandi ${ }^{1}$ \\ Surati ${ }^{2}$ \\ Sri Wahyulina 2
}

\begin{abstract}
This study is based on two-factor theory of Herzberg aimed to explore the influence of motivation on job satisfaction and employee performance at the Local Government institutions. This type of research used in this study is exploratory. The population of as many as 108 employees with a total sample of 51 of Civil Servants in East Lombok regency Regional Secretariat on the work unit is in the coordination of the General Administrative Assistant III. The sampling technique used is the technique Proportionate Stratified Random, data analysis using Partial Least Square (PLS) using software SmatPLS 3. The results stated that the motivation positive and significant impact on performance, motivation positive and significant impact on job satisfaction, job satisfaction and a positive effect significantly to the performance, motivation indirect effect on performance through job satisfaction as a variable intervenig. The implications of this research uses only motivating factor of two-factor theory also has other limitations that situational variables. work behavior and work is an integral Herzberg assume a correlation between satisfaction and productivity. However, research conducted by Herzberg emphasis on customer satisfaction and productivity neglect.
\end{abstract}

Keywords: Motivation, Job Satisfaction, Employee Productivity, Partial Least Square

\section{PENDAHULUAN}

Peningkatan kualitas sumber daya manusia merupakan kebutuhan dalam menghadapi kompleksitas pembangunan daerah tuntutan Peningkatan kualitas Pegawai Negeri Sipil bertujuan untuk mengubah perilaku mereka menjadi lebih profesional dalam bekerja. Untuk meningkatkan Produktivitas organisasi, terlebih dahulu manajemen harus memperbaiki produktivitas individu dengan memperhatikan faktor-faktor yang mempengaruhinnya, selain faktor motivasi dan kepuasan kerja ada beberapa faktor yang mempengaruhi Produktivitas pegawai seperti rekan kerja, kemampuan, pengawasan, peraturan perusahaan, motivasi dan pelatihan (Aamodt, 2010).

Produktivitas adalah perilaku yang nyata yang ditampilkan setiap orang sebagai prestasi kerja yang dihasilkan oleh pegawai sesuai dengan perannya dalam organisasi (Rivai, 2004:309). Dalam rangka mencapai produktivitas pegawai faktor -faktor motivasi perlu mendapatkan perhatian. Menurut Hasibuan (1999:95) motivasi kerja adalah pemberian daya penggerak yang menciptakan kegairahan kerja seseorang, agar mereka mau bekerja sama, bekerja efektif dan terintegrasi dengan segala daya upayanya untuk

\footnotetext{
${ }^{1}$ Mahasiswa Magister Managemen Universitas Mataram

2 Dosen Fakultas Ekonomi dan Bisnis Universitas Mataram
} 


\section{$J M M$ UNRAM \\ JURNAL MAGISTER MANAJEMEN UNIVERSITAS MATARAM

mencapai kepuasan. Robbins dan Judge (2007) mendefinisikan motivasi sebagai proses yang menjelaskan intensitas, arah dan ketekunan usaha untuk mencapai suatu tujuan, dari definisi diatas motivasi kerja diartikan sebagai dorongan atau semangat kerja yang bersumber baik dari dalam diri maupun dari luar yang dilakukan oleh seseorang dalam mengejar suatu tujuan dan berkaitan erat dengan kepuasan kerja dan performansi pekerjaan.

Noermijati (2010) juga menyatakan bahwa kepuasan kerja karyawan menjadi perhatian utama para manajer, akademisi/peneliti dan juga masyarakat umum, karena alasan seseorang masuk menjadi anggota organisasi atau bekerja pada suatu perusahaan diantaranya adalah untuk memperoleh kepuasan kerja. Sedangkan kepuasan kerja yang rendah mengakibatkan produktivitas karyawan juga rendah. Para peneliti lain juga menyatakan hal ini, diantaranya Likert (1961); Herzberg (1957); Yousef (2002), yang melihat hubungan antara faktor motivator/intrinsik dengan kepuasan kerja dan faktor hygiene/ekstrinsik dengan ketidakpuasan kerja. Dan mengilustrasikan kepuasan kerja sebagai keadaan emosi yang menyenangkan atau posif yang dihasilkan dari penilaian atas pekerjaan atau pengalaman kerja seseorang. Kepuasan kerja merupakan hasil dari persepsi karyawan tentang sejauh mana pekerjaan mereka dapat memberikan keadaan emosi seperti itu. Maka sangat penting bagi pengelola organisasi untuk memperhatikan kepuasaan kerja karyawan agar tercapai efisiensi dan efektifitas organisasi melalui karyawan yang puas dan berProduktivitas tinggi (Noermijati, 2010). Cara yang bisa ditempuh adalah dengan meningkatkan produktivitas perusahaan dan peningkatan produktivitas perusahaan ini harus didahului dengan peningkatan Produktivitas sumber daya manusia atau SDM.

Herzberg menyatakan bahwa faktor mutivasional yang mendorong berprestasi kerja yang sifatnya intrinsik, membuat pegawai mencurahkan lebih banyak usaha untuk meningkatkan produktivitasnya. Secara garis besar dapat disimpulkan bahwa motivasi mempunyai peran sangat penting artinya bagi pegawai atau para pemimpin, karena dengan motivasi yang tinggi, maka pekerjaan (tugas) dilakukan dengan bersemangat dan bergairah, sehingga akan dicapai produktivitas tinggi yang tentunya akan mendukung tercapainya tujuan yang diinginkan dengan efisien dan efektif. Motivasi berkaitan dengan kepuasan dan produktivitas, dimana kepuasan dan produktivitas hanya dapat ditingkatkan dengan motivasi yang tinggi, kemauan dan kemampuan dalam melakukan tugas yang didukung dengan lingkungan kerja yang nyaman.

Pada dasarnya produktivitas seorang Pegawai Negeri Sipil merupakan hal yang bersifat individual karena setiap Pegawai Negeri Sipil mempunyai tingkat kemampuan yang berbeda-beda dalam mengerjakan tugas pekerjaannya. Ada beberapa faktor yang dapat mempengaruhi produktivitas pegawai diantaranya dengan menciptakan lingkungan kerja yang baik dan memberian motivasi yang tepat. Lingkungan kerja yang dimaksud, seperti tersedianya perlengkapan dan fasilitas yang memadai, suasana kerja yang menyenangkan akan dapat memberikan produktivitas yang efektif dan efisien dalam penyelesaian pekerjaannya.

Menurut Herzberg (1966) dalam Teck Hong dan Wahed (2011) ada dua jenis faktor yang mendorong seseorang untuk berusaha mencapai kepuasan dan menjauhkan diri dari ketidakpuasan. Dua faktor itu disebutnya factor hygiene (faktor ekstrinsik) dan faktor motivator (faktor intrinsik). Faktor hygiene memotivasi seseorang untuk keluar dari ketidakpuasan, terdiri dari (a). gaji, (b). keamanan kerja, (c). kondisi kerja, (d). pengawasan,(e). hubungan interpersonal, (f). kebijakan dan administrasi sedangkan faktor 


\section{TMM JURNAL MAgISTER MANAJEMEN UNIVERSITAS MATARAM UNRAM

motivator memotivasi seseorang untuk mencapai kepuasan, seperti (a). prestasi, (b). pengakuan, (c). tanggung jawab, (d). sifat pekerjaan, (e). pertumbuhan pribadi dan kemajuan secara signifikan berhubungan dengan kepuasan kerja pegawai (Ncube dan Samuel, 2014).

Hasil penelitian Teck Hong dan Waheed (2011) menunjukkan bahwa setiap organisasi ritel di Malaysia menyiapkan skema reward dan perlu mempertimbangkan empat faktor motivasi seperti (a). kondisi kerja, (b). pengakuan, (c). kebijakan perusahaan (d). uang. Keempat faktor dapat digunakan untuk membantu meningkatkan kepuasan kerja, dan produktivitas tenaga penjualan. Beberapa penelitian seperti Abonam (2011), Nafrizal (2012), Misail (2012), Muogbo (2013), Sidik (2013), Juliantara (2015) Lumantow (2015) membuktikan bahwa motivasi berpengaruh positif dan signifikan terhadap produktivitas . Hasil penelitian Susan et al. (2013) menunjukan bahwa ada pengaruh yang kuat pada produktivitas disebabkan perubahan cara motivasi yang dilakukan oleh manajemen.

Penelitian Brahmasari dan Suprayetno (2010) membuktikan bahwa motivasi kerja berpengaruh positif tetapi tidak signifikan terhadap produktivitas perusahaan, artinya meskipun motivasi kerja perpengaruh positif dan signifikan terhadap kepuasan kerja tetapi belum tentu mempengaruhi produktivitas perusahaan. Akan tetapi penelitian Dhermawan et al, (2012) menyatakan bahwa motivasi berpengaruh tidak signifikan terhadap produktivitas pegawai. Walaupun selama ini diketahui bahwa kepuasan kerja berdampak signifikan terhadap produktivitas pegawai seperti penelitian yang di lakukan Octaviana (2011), namun peneliti juga menemukan adanya hubungan yang tidak signifikan dalam penelitian yang dilakukan Brayfield dan Crocket (dalam Clifford dan Gerasimos (1997) yang menunjukkan lemahnya hubungan antara kepuasan kerja dan produktivitas karyawan. Hal ini menjadi gap research penelitian ini, dan ingin membuktikan di lapangan perbedaan yang ada.

Dalam melihat tingkat kepuasan dan ketidakpuasan kerja pegawai dapat dilihat dari beberapa aspek seperti diungkapkan oleh Ruvendi (2005:17) diantaranya jumlah tingkat kehadiran, perasaan senang maupun tidak senang dalam melakukan pekerjaan, perasaan adil atau tidak adil dalam menerima imbalan, suka atau tidak suka dengan jabatan yang dipegang, sikap menolak pekerjaan atau menerima dengan penuh tanggung jawab, tingkat motivasi pegawai yang tercermin dalam prilaku pekerjaan, reaksi positif dan negatif terhadap kebijakan organisasi, unjuk rasa atau prilaku destruktif lainnya.

Sekretariat Daerah Kabupaten Lombok Timur sebagai pusat pemerintahan di Kabupaten Lombok Timur mempunyai peranan strategis dalam memberikan pelayanan baik kepada masyarakat maupun internal pemerintahan. Dengan demikian diharapkan Sekretariat Daerah mampu melaksanakan fungsi-fungsi pemerintahan dengan sebaikbaiknya terutama fungsi pelayanan. Berdasarkan Perda No 4 Tahun 2008 tentang Struktur Organisasi Perangkat Daerah Pasal 34 ayat 1. Ada delapan bagian pada Sekretariat Daerah. yakni (1). Bagian Tata Pemerintahan, (2). Bagian Hukum, (3). Bagian Ekonomi, (4). Bagian Administrasi Pembangunan, (5). Bagian Kesejahteraan Rakyat, (6). Bagian Umum, (7). Bagian Organisasi, (8). Bagian Humas dan Protokol.

Efektivitas Manajemen Sumber Daya Manusia di lingkungan Sekretariat Daerah Kabupaten Lombok Timur perlu ditingkatkan Hal ini didasarkan atas kondisi nyata yang terjadi terutama produktivitas aparatur belum seluruhnya menunjukkan produktivitas yang optimal seperti dapat dilihat dari tingginya absensi, meningkatnya kelambanan kerja. Dari rata-rata 25 (dua puluh lima) hari kerja setiap bulannya banyak pegawai yang tidak 


\section{$J M M$ UNRAM \\ JURNAL MAGISTER MANAJEMEN

hadir kerja atau absen dengan alasan ijin keperluan keluar dan ijin tanpa keterangan terlambat masuk kerja. Hal ini menunjukkan bahwa ada permasalahan yang perlu mendapatkan perhatian dalam upaya peningkatan produktivitas pegawainya. 
Tabel 1

Tingkat Kehadiran Pegawai Negeri Sipil

Pada Sekertariat Daerah Kabupaten Lombok Timur tahun 2015

\begin{tabular}{|l|l|c|c|c|c|c|c|}
\hline No & Nama Bagian & \multicolumn{7}{|c|}{ Keterangan } \\
\cline { 3 - 8 } & $\begin{array}{c}\text { Sakit } \\
(\mathrm{S})\end{array}$ & $\begin{array}{c}\text { Ijin } \\
(\mathrm{I})\end{array}$ & $\begin{array}{c}\text { Cuti } \\
(\mathrm{C})\end{array}$ & $\begin{array}{c}\text { Tanpa } \\
\text { Keteranga } \\
\mathrm{n} \\
(\mathrm{TK})\end{array}$ & $\begin{array}{c}\text { Tugas } \\
(\mathrm{TG})\end{array}$ & $\begin{array}{c}\text { Terlam } \\
\text {-bat }\end{array}$ & \\
\hline 1 & Organisasi & 7 & 20 & 5 & 30 & 34 & 15 \\
\hline 2 & Umum & 10 & 25 & 7 & 35 & 41 & 33 \\
\hline 3 & $\begin{array}{l}\text { Humas \& } \\
\text { Protokol }\end{array}$ & 24 & 34 & 9 & 15 & 53 & 44 \\
\hline 4 & Hukum & 17 & 44 & 5 & 17 & 34 & 23 \\
\hline 5 & Kesra & 29 & 32 & 10 & 27 & 32 & 45 \\
\hline 6 & Ekonomi & 28 & 5 & 4 & 15 & 25 & 44 \\
\hline 7 & $\begin{array}{l}\text { Tata } \\
\text { Pemerintahan }\end{array}$ & 29 & 16 & 16 & 16 & 36 & 34 \\
\hline 8 & $\begin{array}{l}\text { Administrasi } \\
\text { Pembangunan }\end{array}$ & 19 & 14 & 12 & 18 & 35 & 26 \\
\hline
\end{tabular}

Sumber: Rekap absensi Sekertariat Daerah Kab.Lotim

Sehubungan dengan hal tersebut Sekretariat Daerah Kabupaten Lombok Timur dalam upaya meningkatkan produktivitas pegawainya perlu memperhatikan masalah yang berkaitan dengan motivasi kerja dan kepuasan kerja sehingga dapat lebih memberikan dukungan bagi menajemen dalam meningkatkan produktivitas pegawai secara keseluruhan.

Berdasarkan fenomena yang ada maka penelitian ini bertujuan untuk meneliti pengaruh Motivasi terhadap Produktivitas melalui Kepuasan Kerja Pegawai Negeri Sipil dalam koordinasi Asisten III Administrasi Sekertariat Daerah Kabupaten Lombok Timur

\section{TUJUAN PENELITIAN}

Pertama, untuk mengetahui dan menganalisa pengaruh Motivasi terhadap Produktivitas Pegawai Negeri Sipil dalam koordinasi Asisten III Kabupaten Lombok Timur. Kedua, untuk mengetahui dan menganalisa pengaruh Motivasi terhadap Kepuasan Kerja Pegawai Negeri Sipil dalam koordinasi Asisten III Kabupaten Lombok Timur Ketiga, untuk mengetahui dan menganalisa pengaruh kepuasan kerja terhadap Produktivitas Pegawai Negeri Sipil dalam koordinasi Asisten III Kabupaten Lombok Timur. Keempat, untuk mengetahui dan menganalisa pengaruh Motivasi terhadap Produktivitas pegawai melalui Kepuasan Kerja Pegawai Negeri Sipil dalam koordinasi Asisten III Kabupaten Lombok Timur.

\section{LANDASAN TEORI}




\section{JMM JURNaL M MaCITTER MANAEEEEN UNIVERSITAS MATARAM

\subsection{Motivasi Kerja}

Motivasi kerja adalah daya penggerak yang menciptakan kegairahan kerja seseorang, agar mereka mau bekerja sama, bekerja efektif dan terintegrasi dengan segala daya upayanya untuk mencapai kepuasan kerja dengan motif yang mendorong pegawai untuk melakukan pekerjaan sesuai tugas pokok dan fungsi jabatan yang dinilai atau diukur berdasarkan dimensi motivator Herzberg terdiri dari 4 (empat) indikator diantaranya:

1) Achievement (Prestasi kerja) adalah Keberhasilan seorang pegawai dalam menyelesaikan tugas.

2) Advancement (pengembangan diri) adalah suatu keinginanan seseorang untuk mengembangkan karier dibidang keuangan.

3) Work it self (pekerjaan itu sendiri) adalah variasi pekerjaan dan kontrol atas metode serta langkah-langkah kerja.

4) Recognition (pengakuan) artinya pegawai memperoleh pengakuan, bahwa ia adalah orang, berprestasi baik diberi penghargaan, dan pujian.

3.2 Kepuasan Kerja (Job Satisfaction)

Kepuasan Kerja sebagai keadaan emosi yang menyenangkan atau posif yang dihasilkan dari penilaian atas pekerjaan atau pengalaman kerja seseorang. Kepuasan kerja merupakan hasil dari persepsi karyawan tentang sejauh mana pekerjaan mereka dapat memberikan keadaan emosi seperti itu Analisis faktor eksplorasi dari MSQ menghasilkan empat faktor yang dikonfimatori oleh Fields (2002) dalam Martins dan Proenca (2012). Pada penelitian ini menggunakan tiga faktor tersebut diantaranya

1) Kepuasan Intrinsik adalah perasaan atau sikap seseorang terhadap pekerjaan yang dilakukannya, yang dapat dipengaruhi oleh faktor internal

2) Kepuasan ekstrinsik adalah perasaan atau sikap seseorang terhadap pekerjaan yang dilakukannya, yang dapat dipengaruhi oleh faktor eksternal

3) Otoritas atau utilitas sosial jumlah dari kesenangan atau kepuasan yang dicapai seorang pegawai dalam melaksanakan tugas

3.3 Produktivitas

Produktivitas adalah perilaku kerja yang nyata yang ditampilkan setiap orang sebagai prestasi kerja yang dihasilkan oleh pegawai sesuai dengan perannya dalam organisas. Berdasarkan pasal 4 Peraturan Pemerintah No. 46 Tahun 2011, penilaian prestasi kerja dengan Indikator sebagai berikut:

1) Orientasi pelayanan merupakan sikap dan perilaku kerja PNS dalam memberikan pelayanan kepada yang dilayani antara lain meliputi masyarakat, atasan, rekan sekerja, unit kerja terkait, dan/atau instansi lain.

2) Integritas merupakan kemampuan seorang PNS untuk bertindak sesuai dengan nilai, norma dan etika dalam organisasi.

3) Komitmen merupakan kemauan dan kemampuan seorang PNS untuk dapat menyeimbangkan antara sikap dan tindakan untuk mewujudkan tujuan organisasi dengan mengutamakan kepentingan dinas daripada kepentingan diri sendiri, seseorang, dan/atau golongan.

4) Disiplin merupakan kesanggupan seorang PNS untuk menaati kewajiban dan menghindari larangan yang ditentukan dalam peraturan perundang-undangan atau peraturan kedinasan yang apabila tidak ditaati atau dilanggar dijatuhi sanksi. 


\section{$J M M$ \\ UNRAM \\ JURNAL MAGISTER MANAJEMEN \\ UNIVERSITAS MATARAM \\ VOL. 5 NO. 4 NOVEMBER 2016}

5) Kerja sama merupakan kemauan dan kemampuan seorang PNS untuk bekerja sama dengan rekan sekerja, atasan, bawahan baik dalam unit kerjanya maupun instansi lain dalam menyelesaikan suatu tugas dan tanggung jawab yang diembannya.

6) Kepemimpinan merupakan kemampuan dan kemauan PNS untuk memotivasi dan mempengaruhi bawahan atau orang lain yang berkaitan dengan bidang tugasnya demi tercapainya tujuan organisasi.

\section{KERANGKA KONSEPTUAL}

Gambar 1 Model Struktural

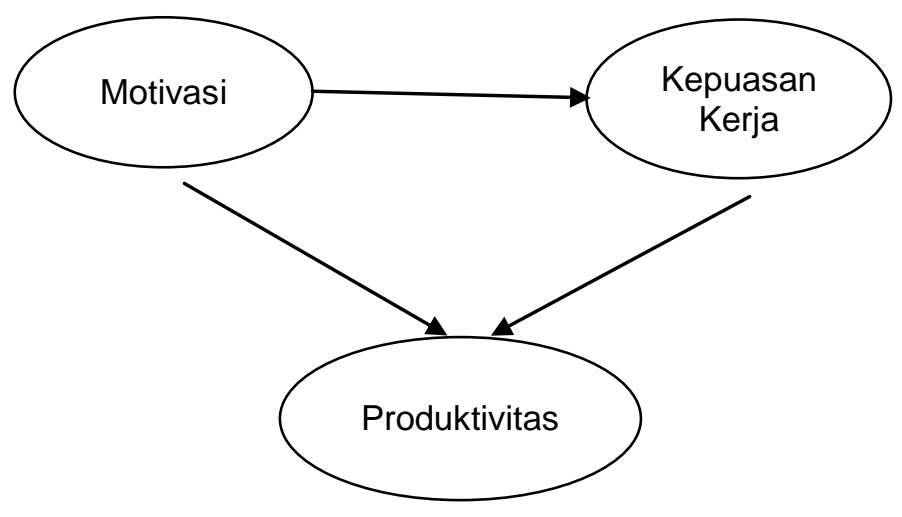

\section{HIPOTESIS}

Berdasarkan kajian teori dan hasil penelitian terdahulu, maka disusun hipotesis penelitian pertama yaitu:

H1 :Diduga Motivasi kerja berpengaruh positif dan signifikan terhadap Produktivitas Pegawai Negeri Sipil dalam Koordinasi Asisten III Kabupaten Lombok Timur.

Hipotesis pertama akan menganalisis pengaruh motivasi terhadap produktivitas pegawai. Motivasi Pegawai Negeri Sipil merupakan hal yang sangat penting bagi organisasi publik terutama peningkatan produktivitas Kerja. Sejalan dengan yang ditemukan oleh Shanthakumary (2012), Muogbo (2013), Chaudhary (2012), Abonam (2011), Teck Hong dan Waheed (2011), Susan et al. (2013), Mahesa (2010), Octaviana (2011), bahwa motivasi mempunyai pengaruh yang signifikan terhadap produktivitas pegawai, namun hasil dari Noermijati (2008) menghasilkan bahwa Motivasi tidak berpengaruh langsung terhadap produktivitas manajer operasional. Hal ini merupakan variasi dari hasil penelitian terdahulu yang memicu pertanyaan dan akan diteliti dalam penelitian kali ini.

H2 : Diduga Motivasi kerja berpengaruh positif dan signifikan terhadap Kepuasan Kerja Pegawai Negeri Sipil dalam Koordinasi Asisten III Kabupaten Lombok Timur. 


\section{IMM JURNAL MAGISTER MANAJEMEN UNIVERSITAS MATARAM

Hipotesis kedua menganalisa mengenai teori dua faktor herzberg yang kedua yaitu motivasi interinsik. Apakah akan mempengaruhi kepuasan dan produktivitas pegawai atau tidak. Pemberian motivasi yang cocok oleh pimpinan untuk para pegawai cenderung akan menimbulkan kepuasan pada diri pegawai, sehingga terciptalah keikhlasan pegawai dalam bekerja. Karena, hubungan seseorang dengan pekerjaannya sangat mendasar dan karena itu sikap seseorang terhadap pekerjaannya itu sangat mungkin menentukan kepuasan atau ketidakpuasan dalam pekerjaan (Herzberg, 1959). Seperti halnya yang ditemukan oleh Ncube dan Samuel (2014), Collie et al., (2012), Maharjan (2012), Mazlomi et al. (2014), Sultan (2012), dan Klassen et al. 2010,. 2012, Juniantara, I.W 2015, Octaviana (2011), dan Lumantow,et al. 2015. yang menunjukan bahwa motivasi berpengaruh positif dan signifikan terhadap kepuasan kerja .

H3 : Diduga Kepuasan kerja berpengaruh positif dan signifikan terhadap Produktivitas Pegawai Negeri Sipil dalam Koordinasi Asisten III Kabupaten Lombok Timur.

Kepuasan kerja merupakan hasil dari persepsi Pegawai Negeri Sipil tentang sejauh mana pekerjaan mereka dapat memberikan keadaan emosi seperti itu. Maka sangat penting bagi individu dan manajemen untuk memperhatikan kepuasaan kerja Pegawai Negeri Sipil agar tercapai efisiensi dan efektifitas organisasi melalui Pegawai yang puas dan berproduktivitas tinggi (Noermijati, 2010). Pada penelitian terdahulu juga telah dikemukakan bahwa kepuasan kerja memiliki pengaruh yang signifikan terhadap produktivitas pegawai, seperti yang ditemukan oleh Noermijati (2008), Misail P.et al. (2012), Mahesa (2010), Siregar et al (2014), Lumantow, et al (2015), Brahmasari dan Suprayetno (2008), dan Octaviana (2011).

H4 : Diduga Motivasi berpengaruh Positif terhadap Produktivitas Melalui Kepuasan Kerja Pegawai Negeri Sipil dalam Koordinasi Asisten III Kabupaten Lombok Timur.

Pada hipotesis keempat akan diteliti mengenai pengaruh tidak langsung antara motivasi terhadap produktivitas pegawai melalui kepuasan kerja, sebagaimana yang telah ditemukan oleh Octaviana (2011), Widyastuti (2004), dan Noermijati (2008) yang mengemukakan bahwa motivasi mempunyai pengaruh tidak langsung yang signifikan terhadap produktivitas pegawai melalui kepuasan kerja.

\section{METODE PENELITIAN}

Penelitian ini merupakan penelitian kausalitas bertujuan menguji hubungan Motivasi terhadap Produktivitas Pegawai Negeri Sipil dengan Kepuasan Kerja sebagai variable intervening, dengan jenis penelitian yang digunakan adalah penelitian eksploratoris, dilakukan dengan cara menjelaskan gejala yang ditimbulka oleh suatu objek penelitian untuk menguji hubungan antara variabel yang dihipotesakan. Populasi dalam penelitian ini adalah seluruh Pegawai Negeri Sipil pada unit organisasi dibawah koordinasi Asisten III Sekertariat Daerah Kabupaten Lombok Timur yang terdiri dari Bagian Umum 60 orang, Bagian Organisasi 16 orang, Bagian Humas dan Protokol 27 orang total 103 Pegawai Negeri Sipil 


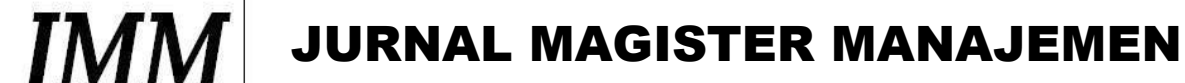 UNIVERSITAS MATARAM UNRAM

dengan sampel sebanyak 51 orang Pegawai Negeri Sipil. Metode pengambilan sampel dalam penelitian ini digunakan teknik propotionate stratified random sampling .

\section{PEMBAHASAN}

\subsection{Deskripsi responden Penelitian}

Responden berdasarkan umur didominasi oleh responden berumur 30 sampai dengan 40 tahun sebesar $53 \%$, mengindikasikan tingginya kuantitas pegawai dengan umur produktif yang bekerja pada obyek penelitian. Ditinjau dari jenis kelamin, didominasi Pegawai Negeri Sipil Laki-laki sebesar $80 \%$ dan sisanya $20 \%$ berjenis kelamin perempuan hal tersebut dipengaruhi oleh karakteristik pekerjaan yang ada pada saat ini dan proses rekruetmen pegawai pada masa lalu yang berasal dari tenaga kontrak yang sebagian besar diisi oleh lakilaki, proses mutasi dan promosi di internal lebih cenderung bersesuaian dengan kompetensi laki-laki.

Pada posisi jabatan yang tersedia pun ditemukan hal yang sama masih didominasi oleh pegawai Laki-laki yang menduduki jabatan yang ada pada Bagian Sekertariat Daerah dalam koordinasi Asisten III Setda Kab. Lotim. Dalam setiap posisi atau jabatan di internal tidak ditentukan syarat jenis kelamin. Dilihat dari latar belakang pendidikan, sebagian besar pegawai mempunyai latar belakang SI (sarjana) yaitu 52 orang (73\%) hal ini dipengaruhi sebagian besar pegawai negeri yang semula hanya berpendidikan SMA diberikan ijin belajar untuk melanjutkan studinya selain itu pula proses rekruetmen Pegawai Negeri Sipil tiga Tahun Terakhir disyaratkan minimal berpendidikan SI. Sedangkan pegawai yang berpendidikan S2 sebanyak 7\% diisi oleh pejabat struktural yang mendapatkan ijin dan tugas belajar dari Pemerintah Daerah.

\subsection{Uji Validitas dan Reliabilitas}

Berdasarkan hasil analisa diketahui bahwa instrumen penelitian yang digunakan memiliki skor product moment lebih dari 0.3 dengan taraf signifikansi kurang dari 5 persen sehingga semua butir dalam instrument dikatakan valid.sedangkan untuk pengukuran reliabilitas diketahui bahwa Alpha Cronbach seluruh instrument lebih besar daripada 0.6. Hal ini menunjukkan bahwa pengukuran tersebut dapat memberikan hasil yang konsisten apabila dilakukan pengukuran kembali terhadap subyek yang sama.

\subsection{Deskripsi Variabel Penelitian}

Indikator yang mempunyai rata-rata skor tertinggi pada variabel Motivasi adalah indikator Advancement (pengembangan diri) sebesar 4.20. Sementara indikator Achievement (Prestasi kerja) memiliki rata-rata skor terendah yaitu 4.12. Hasil ini memberi makna bahwa pegawai lebih memperhatikan pengembangan diri untuk meningkatkan kompetensi dalam bekerja yang nantinya dapat mendukung memperoleh prestasi kerja.

Variabel Kepuasan Kerja diukur dengan menggunakan tiga indikator dengan sekor tertinggi adalah Kepuasan Kerja Ekstrinsik sebesar 4.20 sedangkan kepuasan kerja dengan skor terendah adalah kepuasan kerja intrinsik sedangkan kepuasan kerja dengan indikator konstruk otoritas sebesar kebijakan yang diterapkan manajemen atau atasan pada Bagian unit kerja dalam koordinasi Asisten III Administrasi Umum Sekertariat Daerah Lombok Timur menjadikan suatu dorongan bagi pegawai menjadi puas dalam bekerja lebih baik. 


\section{$J M M$ UNRAM \\ JURNAL MAGISTER MANAJEMEN UNIVERSITAS MATARAM

Produktivitas Pegawai Negeri Sipil ditemukan bahwa nilai dari Orientasi Pelayanan Pegawai sebesar 4.18 dan merupakan skor tertinggi sedangkan indikator Kepemimpinan dan Disiplin memiliki nilai skor terendah sebesar 4.12 secara umum keenam indikator pembentuk prilaku produktivitas pegawai nilai rerata masing- masing indikator produktivitas mendapat respon baik dari pegawai.

\subsection{Evaluasi Fit Model}

Outer Model atau Measurement Model terdiri dari tiga kriteria di dalam penggunaan teknik analisa data dengan SmartPLS untuk menilai outer model yaitu Convergent Validity, Discriminant Validity, dan Composite Reliability. Hasil uji Convergent Validity menunjukkan bahwa seluruh indikator pada masing-masing variabel memiliki loading factor lebih dari 0.50 sampai 0.6 dianggap cukup memadai. Ukuran refleksif individual dikatakan tinggi jika berkorelasi lebih dari 0.70 dengan variabel yang diukur. Nilai outer model atau korelasi antar variabel dengan variabel telah melengkapi convergent validity karena seluruh memiliki nilai loading factor di atas 0.50 .

Tabel 2 Outer Loadings (Measurement Model)

\begin{tabular}{|c|l|c|}
\hline Variabel & \multicolumn{1}{|c|}{ Indikator } & $\begin{array}{c}\text { Outer } \\
\text { Loading }\end{array}$ \\
\hline \multirow{4}{*}{ Motivasi } & Achievement (Prestasi kerja) & 0.908 \\
\cline { 2 - 3 } & Advancement (pengembangan diri) & 0.936 \\
\cline { 2 - 3 } & Work it self (pekerjaan itu sendiri) & 0.935 \\
\cline { 2 - 3 } Kepuasan & Recognition (pengakuan) & 0.965 \\
\hline Kerja & Kepuasan Intrinsik & 0.924 \\
\cline { 2 - 3 } & Kepuasan ekstrinsik & 0.776 \\
\cline { 2 - 3 } Produktivitas & Otoritas/utilitas social & 0.882 \\
\cline { 2 - 3 } & Orientasi Pelayanan & 0.873 \\
\cline { 2 - 3 } & Integritas & 0.771 \\
\cline { 2 - 3 } & Komitmen & 0.832 \\
\cline { 2 - 3 } & Disiplin & 0.879 \\
\cline { 2 - 3 } & Kerjasama & 0.913 \\
\cline { 2 - 3 } & Kepemimpinan & 0.905 \\
\hline
\end{tabular}

Sumber : hasil analisa (Lampiran 5)

Discriminant validity dilakukan untuk memastikan setiap konsep dari masingmasing variabel laten yang berbeda dengan variabel lainnya. Model dikatakan mempunyai discriminant validity yang baik apabila setiap nilai loading indikator dari sebuah variabel laten mempunyai nilai loading yang lebih besar dari nilai loading jika dikorelasikan dengan variabel laten lainnya.

Tabel 3 Discriminant Validity

\begin{tabular}{|l|c|c|c|c|c|}
\hline \multicolumn{3}{|c|}{ AVE } & \multicolumn{3}{c|}{ Korelasi } \\
\hline & AVE & Akar AVE & $\begin{array}{c}\text { Kepuasan } \\
(\mathrm{Z})\end{array}$ & $\begin{array}{c}\text { Motivasi } \\
(\mathrm{X})\end{array}$ & $\begin{array}{c}\text { Produktivitas } \\
(\mathrm{Y})\end{array}$ \\
\hline Kepuasan (Z) & 0.745 & 0.863 & 0.863 & & \\
\hline Produktivitas (Y) & 0.877 & 0.936 & 0.876 & 0.936 & \\
\hline
\end{tabular}




\section{$J M M$ \\ UNRAM \\ JURNAL MAGISTER MANAJEMEN \\ UNIVERSITAS MATARAM \\ VOL. 5 NO. 4 NOVEMBER 2016}

\begin{tabular}{|l|l|l|l|l|l|}
\hline Motivasi $(X)$ & 0.745 & 0.863 & 0.873 & 0.913 & 0.863 \\
\hline
\end{tabular}

Sumber : hasil analisa (Lampiran 5 )

Dari pengujian discriminant validity menunjukan bahwa hasil ketiga variabel memiliki nilai AVE diatas 0.50 dan semua variabel memiliki nilai akar AVE lebih tinggi dari koefisien korelasi antar satu variabel dengan variabel lainnya sehingga dapat dikatakan data memiliki discriminant validity yang baik.

Kriteria validity dan reliabilitas juga dapat dilihat dari nilai reliabilitas suatu variabel dan nilai Average Variance Extracted (AVE) dari masing- masing variabel. Variabel dikatakan memiliki reliabilitas yang tinggi jika nilai composite reliablity diatas 0.70 dan AVE berada diatas 0.50. Dalam hal ini seluruh variabel memenuhi composite reliability karena nilainya diatas angka yang direkomendasikan, yaitu diatas 0.7 yang sudah memenuhi kreteria realibel.

Tabel 4 Composite Reliability

\begin{tabular}{|c|c|}
\hline Variabel & Composite Reliability \\
\hline Motivasi & 0.897 \\
\hline Kepuasan Keria & 0.966 \\
\hline Produktivitas & 0.946 \\
\hline
\end{tabular}

Sumber : hasil analisa (Lampiran 5)

Pengujian inner model atau model struktural dilakukan untuk melihat hubungan antara variabel, nilai signifikansi dan R-square dari model penelitian. Penilaian model dengan PLS dimulai dengan melihat R-square untuk setiap variabel laten dependen. Perubahan nilai R-square dapat digunakan untuk menilai pengaruh variabel laten eksogen tertentu terhadap variabel laten endogen yang mempunyai pengaruh substantif.

Gambar 2 Model Struktural 


\section{$J M M$ \\ UNRAM \\ JURNAL MAGISTER MANAJEMEN \\ UNIVERSITAS MATARAM \\ VOL. 5 NO. 4 NOVEMBER 2016}

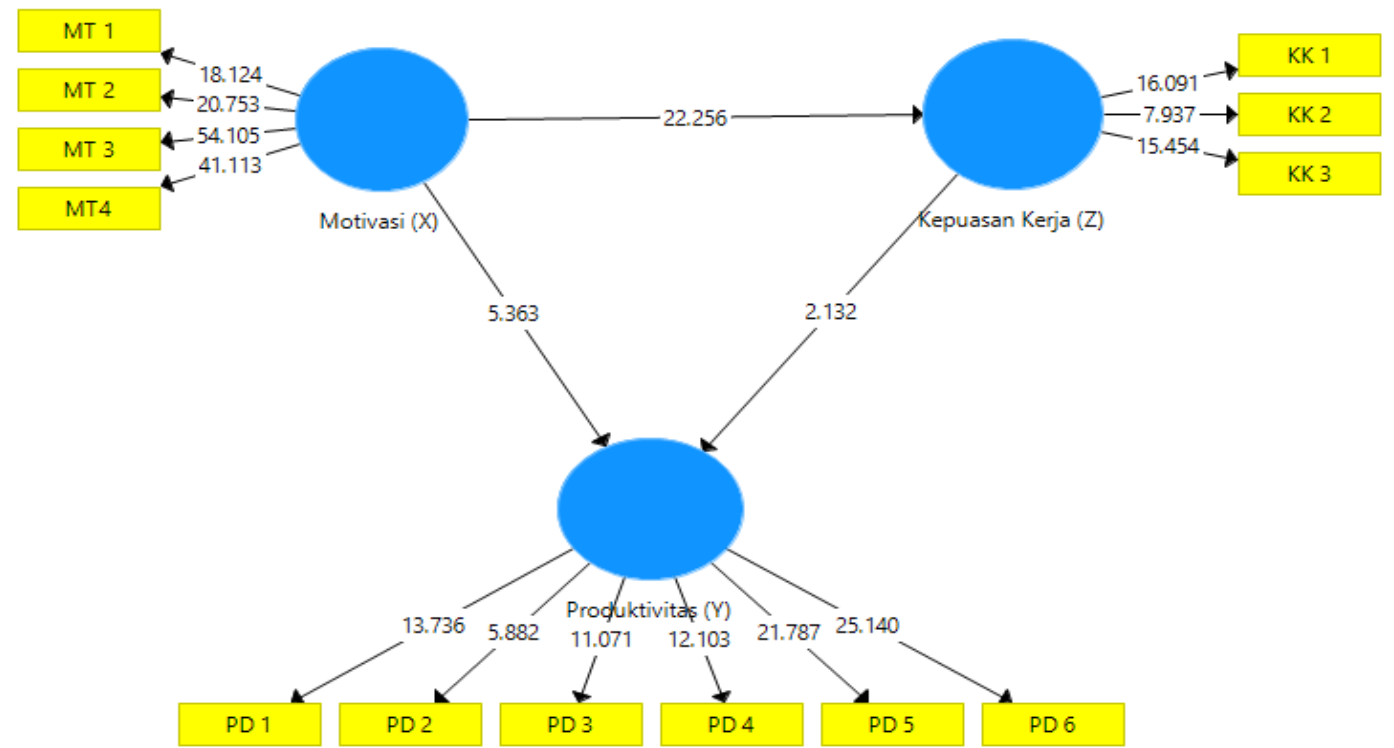

Hasil estimasi menunjukkan nilai R-square variabel kepuasan kerja memiliki nilai $\mathrm{R}$ square sebesar 0.289 yang berarti $28.9 \%$ variance motivasi mampu dijelaskan oleh variabel kepuasan kerja sedangkan sisanya dijelaskan oleh variabel lain di luar model penelitian. Variabel Produktivitas memiliki nilai R-square 0.206 berarti $20.6 \%$ variance motivasi mampu dijelaskan oleh variabel Produktivitas sedangkan sisanya dijelaskan oleh variabel lain di luar model penelitian. 


\section{TMM JURNAL MAgISTER MANAJEMEN UNIVERSITAS MATARAM

Tabel 5 Nilai $R$-Square

\begin{tabular}{|c|c|}
\hline Variabel & R Square \\
\hline Motivasi $(\mathrm{X})$ & \\
\hline Kepuasan $(\mathrm{Z})$ & 0.767 \\
\hline Produktivitas $(\mathrm{Y})$ & 0.857 \\
\hline
\end{tabular}

Sumber : hasil analisa (Lampiran 5)

Selain dengan menggunakan R-square, goodness of fit model juga diukur dengan menggunakan Q-Square predictive relevance untuk model struktural, Hasil Q -squere diketahui sebesar 0.97 atau sebesar 97\% untuk Motivasi dan Kepuasan kerja yang merupakan variable independen yang memberikan pengaruh terhadap Produktivitas pegawai sebesar 97\% menunjukan bahwa bahwa model memiliki predictive relevance karna memiliki nilai lebih besar dari nol. Berarti semakin layak digunakan dalam prediksi. Berdasarkan hasil perhitungan ini juga memberikan arti bahwa masih ada $3 \%$ variable lainnya yang dapat mempengaruhi variable Produktivitas diluar model yang tidak di teliti misalnya karakteristik personal,kompensasi finansial, keamanan kerja kebijakan dll.

Hasil analisis data menunjukan bahwa motivasi terdapat pengaruh positif dan signifikan terhadap Produktivitas pegawai. Ini artinya motivasi yang diukur melalui empat indikator yaitu: achievement (prestasi kerja), advancement (pengembangan diri), work it self (pekerjaan itu sendiri), recognition (pengakuan), berpengaruh positif dan signifikan terhadap Produktivitas pegawai. Hal ini memberikan petunjuk bahwa hipotesis diterima. Cara motivasi yang diterapkan oleh manajemen dilihat dari manfaat langsung yang dirasakan.

\subsection{Pengujian Hipotesis}

Signifikansi parameter yang diestimasi memberikan informasi yang sangat berguna mengenai hubungan antara variabel-variabel penelitian. Dasar yang digunakan dalam menguji hipotesis adalah nilai yang terdapat pada output result for inner weight. Tabel 6 memberikan output estimasi untuk pengujian model struktural.

Tabel 6 Result For Inner Weights

\begin{tabular}{|l|c|c|c|c|}
\hline \multicolumn{1}{|c|}{ Hipotesa } & $\begin{array}{c}\text { Original } \\
\text { Sample }(\mathrm{O})\end{array}$ & $\begin{array}{c}\text { Standard } \\
\text { Deviation } \\
(\mathrm{STDEV})\end{array}$ & $\begin{array}{c}\text { TStatistics } \\
(|\mathrm{O} / \mathrm{STDEV}|)\end{array}$ & Kesimpulan \\
\hline $\begin{array}{l}\text { Kepuasan Kerja (Z) -> } \\
\text { Produktivitas }(\mathrm{Y})\end{array}$ & 0.311 & 0.114 & 2.733 & Diterima \\
\hline $\begin{array}{c}\text { Motivasi }(\mathrm{X})->\text { Kepuasan Kerja } \\
(\mathrm{Z})\end{array}$ & 0.876 & 0.046 & 19.092 & Diterima \\
\hline $\begin{array}{c}\text { Motivasi }(\mathrm{X}) \text {-> Produktivitas } \\
(\mathrm{Y})\end{array}$ & 0.641 & 0.107 & 6.000 & Diterima \\
\hline $\begin{array}{c}\text { Motivasi }(\mathrm{X}) \text {-> Kepuasan Kerja } \\
(\mathrm{Z})->\text { Produktivitas }(\mathrm{Y})\end{array}$ & 0.273 & 0,052 & 52,178 & Diterima \\
\hline
\end{tabular}

Sumber : hasil analisa (Lampiran 5)

Pengujian Hipotesis 1: Pengaruh Motivasi terhadap Produktivitas Pegawai

Hipotesis 1 menyatakan bahwa motivasi berpengaruh positif dan signifikan terhadap

Produktivitas. Hasil uji terhadap koefisien parameter antara motivasi terhadap 


\section{$J M M$ UNRAM \\ JURNAL MAGISTER MANAJEMEN UNIVERSITAS MATARAM VOL. 5 No. 4 NOVEMBER 2016}

Produktivitas menunjukkan adanya hubungan yang positif dengan nilai koefisien sebesar 0.641 dengan nilai t-statistik sebesar 6.000 dan signifikan pada $\alpha=0.05$. Nilai t- statistik tersebut berada diatas nilai kritis 1.96, dengan demikian $\mathrm{H} 0$ diterima.

Hasil analisis data menunjukan bahwa pengaruh langsung maupun tidak langsung motivasi melalui Kepuasan Kerja terdapat Produktivitas Pegawai berpengaruh positif dan signifikan. Ini artinya motivasi yang diukur melalui empat indikator yaitu: achievement (prestasi kerja), advancement (pengembangan diri), work it self (pekerjaan itu sendiri), recognition (pengakuan) berpengaruh positif dan signifikan terhadap Produktivitas pegawai secara langsung dan pengaruh motivasi melalui kepuasan kerja dengan tiga indikator kepuasan kerja berpengaruh positif dan signifikan. Hal ini memberikan petunjuk bahwa hipotesis satu dan empat diterima. Cara motivasi yang diterapkan oleh manajemen dilihat dari manfaat langsung yang dirasakan oleh pegawai berdampak positif dan signifikan terhadap Produktivitas, semakin baik motivasi yang dilakukan oleh manajemen terhadap pegawai maka semakin puas pegawai dan mengantarkan pada Produktivitas yang baik dihasilkan pegawai .

Hasil penelitian ini sejalan dengan penelitian yang dilakukan antara lain Juniantara (2015), Dhermawan (2012), Muogbo (2013), Maharjan (2012), Sidik (2013), Misail P. (2012), Shanthakumary (2012), Muogbo (2013), Chaudhary (2012), Abonam (2011), Teck Hong dan Waheed (2011), Susan et al. (2013), Mahesa (2010), Octaviana (2011), bahwa motivasi mempunyai pengaruh positif yang signifikan terhadap produktivitas pegawai, namun berbeda dengan hasil dari Noermijati (2008) menyatakan bahwa Motivasi tidak berpengaruh langsung terhadap produktivitas. Berdasarkan penelitian ini dapat dijelaskan bahwa motivasi kerja memang sangat diperlukan oleh seorang pegawai untuk mencapai Perilaku Produktiv untuk menghasilkan outpu kinerja yang baik sebagai tolak ukur penilaian prestasi kerja (Produktivitas) pegawai yang telah disepakati pada awal tahun dengan atasan masingmasing pada tiap tahunya pada bagian unit kerja pada Sekertariat Daerah Kabupaten Lombok Timur.

\section{Pengujian Hipotesis 2: Pengaruh Motivasi terhadap Kepuasan Kerja}

Hipotesis 2 menyatakan bahwa motivasi berpengaruh positif dan signifikan terhadap kepuasan kerja. Hasil uji terhadap koefisien parameter antara motivasi terhadap kepuasan Kerja menunjukkan adanya hubungan yang positif dengan nilai koefisien sebesar 0.876 dengan nilai t-statistik sebesar 19.092 dan signifikan pada $a=0.05$. Nilai t-statistik tersebut berada pada diatas nilai kritis 1.96, dengan demikian H0 diterima. Cara motivasi yang diterapkan oleh manajemen dilihat dari manfaat langsung yang dirasakan oleh pegawai berdampak positif dan signifikan terhadap kepuasan kerja. Hal ini mengandung arti bahwa semakin baik dan meningkat motivasi yang diberikan pada kepada pegawai maka kepuasan kerja pegawai akan meningkat.

Temuan ini sesuai dengan apa yang dikemukakan oleh herzberg (1959) bahwa Herzberg berpendapat bahwa apabila para manajer ingin memberikan motivasi pada bawahannya, yang perlu ditekankan adalah faktor-faktor yang menimbulkan rasa puas, yaitu dengan mengutamakan faktor-faktor motivasional yang bersifat internal. Selain itu As'ad (1996) mengemukakan bahwa dengan seringnya para pegawai/karyawan termotivasi untuk melakukan pekerjaannya dengan baik, akan meningkatkan kualitas dan kepuasan kerja yag diinginkan, karena kuat lemahnya dorongan atau motivasi kerja seseorang akan menentukan besar kecilnya kepuasan kerja. 


\section{IMM JURNAL MAGISTER MANAJEMEN UNIVERSITAS MATARAM UNRAM

Selanjutnya, pada penelitian terdahulu juga ditemukan bahwa motivasi intrinsik berpengaruh terhadap kepuasan kerja (Noermijati, 2008), (Nugraheni, 2003), (Octaviana,2011), (Widyastuti, 2004), (purnomowati, 2006), dan (Brahmasari dan Suprayetno 2008). Penelitian ini sejalan dengan penelitian yang dilakukan oleh Teck Hong dan Waheed (2011), Collie et al. (2012), Maharjan (2012) Lumantow et al. (2015), Misail P. (2012), Mastika W. (2010) Sidik Priadana, et al. (2013). Berdasarkan penelitian ini dapat dijelaskan bahwa motivasi kerja memang sangat diperlukan oleh seorang pegawai untuk dapat mencapai suatu kepuasan kerja yang tinggi meskipun menurut sifatnya kepuasan kerja itu sendiri sangat relatif atau berbeda antara satu orang dengan orang lainnya.

Pengujian Hipotesis 3: Pengaruh Kepuasan Kerja terhadap Produktivitas.

Hipotesis 3 menyatakan bahwa kepuasan kerja berpengaruh positif dan signifikan terhadap Produktivitas. Hasil uji terhadap koefisien parameter antara kepuasan kerja terhadap Produktivitas menunjukkan adanya hubungan yang positif dengan nilai koefisien sebesar 0.311 dengan nilai t-statistik sebesar 2.733 dan signifikan pada $\alpha=0.05$. Nilai t-statistik tersebut berada diatas nilai kritis 1.96, dengan demikian $\mathrm{H} 0$ diterima. Hal ini mengandung arti bahwa semakin meningkat kepusan kerja seorang pegawai maka semakin meningkat pula Produktivitas seorang pegawai. Penelitian ini sejalan dengan penelitian yang telah dilakukan oleh beberapa peneliti sebelumnya diantaranya : Zulhana. (2012) Misail P. (2012), Noermijati, (2008), Helena dan Proenca (2012), Susan (2012), Sidik. P, et al. (2013) Siregar (2014), yang menyatakan bahwa kepuasan kerja berpengaruh positif terhadap Produktivitas pegawai

Berdasarkan penelitian ini dapat dijelaskan bahwa kepuasan kerja memang sangat diperlukan oleh seorang pegawai dalam meningkatkan Produktivitas masing-masing individu meskipun menurut sifatnya kepuasan kerja itu sendiri sangat relatif atau berbeda antara satu orang dengan orang lainnya.

Pengujian Hipotesis 4: Pengaruh tidak langsung Motivasi terhadap Produktivitas melalui Kepuasan Kerja.

Hipotesis 4 menyatakan bahwa Motivasi berpengaruh tidak langsung terhadap Produktivitas melalui Kepuasan Kerja sebagai variabel intervening. Hasil uji terhadap koefisien parameter antara motivasi terhadap Produktivitas melalui kepuasan kerja menunjukkan adanya hubungan dengan nilai t-statistik sebesar 2.733X $19.092=52.178$ dan signifikan pada $a=0.05$. Nilai $t$-statistik tersebut berada diatas nilai kritis 1.96 , dengan demikian $\mathrm{H} 0$ diterima.

Motivasi berpengaruh signifikan terhadap produktivitas pegawai. Koefisien yang positif mengindikasikan bahwa motivasi memberikan pengaruh yang positif terhadap produktivitas pegawai. Yang berarti semakin tinggi motivasi pegawai, maka produktivitas pegawai akan semakin tinggi pula. Sebaliknya, semakin rendah motivasi pegawai, maka produktivitas pegawai juga akan semakin rendah.

Temuan ini sesuai dengan apa yang dikemukakan penelitian terdahulu bahwa motivasi berpengaruh secara langsung terhadap produktivitas pegawai (Nugraheni, 2003), (Octaviana, 2011), (Widyastuti, 2004), (purnomowati, 2006), dan (Brahmasari dan Suprayetno 2008).

Motivasi berpengaruh signifikan secara tidak langsung terhadap produktivitas pegawai. Koefisien yang positif mengindikasikan bahwa motivasi memberikan pengaruh yang positif secara tak langsung terhadap kinerja pegawai dengan melalui kepuasan kerja sebagai intervening. Semakin tinggi motivasi intrinsik pegawai, akan berdampak pada 


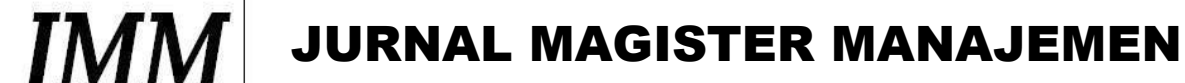 UNIVERSITAS MATARAM UNRAM

meningkatnya kepuasan kerja dan akan berdampak pada meningkatnya produktivitas pegawai.

Penelitian terdahulu mengungkapkan bahwa motivasi intrinsik mempunyai pengaruh tidak langsung terhadap produktivitas pegawai melalui kepuasan kerja (Temuan ini sesuai dengan apa yang dikemukakan Noermijati, 2008) dan (Octaviana, 2011).

\section{KESIMPULAN DAN SARAN}

Berdasarkan hasil penelitian pada responden Pegawai Negeri Sipil dalam koordinasi asisten III Administrasi umum Sekertariat Daerah Kabupaten Lombok Timur ini, maka dapat disimpulkan beberapa hal sebagai berikut ini :

1. Motivasi berpengaruh positif dan signifikan terhadap produktivitas. Hal ini menunjukan bahwa semakin baik dan meningkat motivasi yang diberikan oleh manajemen atau atasan terhadap pegawai, maka produktivitas pegawai akan semakin meningkat dan mencapai visi dan misi organisasi.

2. Motivasi berpengaruh positif dan signifikan terhadap kepuasan kerja. Hal ini menunjukkan bahwa semakin meningkat motivasi yang diberikan oleh manajemen atau atasan kepada pegawai, maka kepuasan kerja pegawai akan semakin meningkat.

3. Kepuasan kerja berpengarurh positif dan signifikan terhadap produktivitas. Hal ini menunjukan bahwa semakin tinggi dan meningkat kepuasan pegawai, maka produktivitas pegawai akan semakin meningkat.

4. Motivasi perpengaruh positif dan signifikan baik secara langsung atau tidak langsung melalui kepuasan kerja terhadap produktivitas pegawai, hal ini menunjukan bahwa adanya motivasi pegawai dapat memberikan atau meningkatkan kepuasan kerja pegawai berdampak pada perubahan perilaku produktif. Pegawai menyukai pekerjaan dan menjalankan ketentuan indikator penilaian prestasi pegawai sesuai dengan Peraturan Pemerintah No 46 Tahun 2014.

Berdasarkan pembahasan dan simpulan yang telah dikemukakan sebelumnya, maka saran dari penelitian ini adalah :

1. Untuk mempertahankan kepuasan kerja dan produktivitas pegawai, manajemen hendaknya mempertahankan beberapa faktor seperti prestasi kerja, pengakuan terhadap produktivitas pegawai ,hubungan kondusif antara pegawai dengan rekan kerja dan atasan, dan kebijakan yang diterapkan oleh manajemen. Untuk meningkatkan kepuasan kerja dan produktivitas pegawai manajemen hendaknya memberikan atau memfasilitasi pegawai untuk mengembangkan dan pelatihan diri. guna meningkatkan kopetensi dan kepercayaan diri pegawai. selain itu pula manajemen atau atasan harus memanfaatkan keterampilan pegawai dan kompetensi mereka secara maksimal melalui penerapan teori motivasi Herzberg di , diharapkan dapat meningkatkan kepuasan kerja dan produktivitas pegawai .

2. Untuk penelitian selanjutnya agar menggunakan faktor motivasi dan hygiene faktor serta lebih banyak menggunakan variabel dan melibatkan banyak responden dalam melakukan penelitian sehingga dapat menghasilkan hasil yang lebih baik. Karena dalam teori motivasi (Herzberg) telah diperhitungkan bahwa tidak semua teori motivasi dapat 


\section{IMM JURNAL MAgISTER MANAJEMEN UNIVERSITAS MATARAM

diterapkan di dalam, organisasi terhadap pegawai , karena masing-masing pegawai, insitusi swasta dan institusi publik memiliki tujuan, kebutuhan dan kepentingan yang berbeda sehingga teori Herzberg dipandang perlu untuk dipertimbangkan didalam mengukur kepuasan dan produktivitas pegawai.

\section{DAFTAR PUSTAKA}

Abonam, Nehorbuno Dominic. (2011), "The Roll Employee Performance in the Public Sector": Thesis. Case Study of the University for Development Studies-Wa Campus.

Aamodt, Michael G. (2010). Industrial/Orgnizational Psychology: an aplied approach. 6th Ed. Amerika Serikat: Wadsworth

Arikunto, S. (1998). “Prosedur Penelitian: Suatu Pendekatan Praktek”, Rajawali Press, Jakarta.

Brahmasari Ida Ayu,Suprayetno, A. (2008) "Pengaruh Motivasi Kerja, Kepemimpinan dan Budaya Organisasi Terhadap Kepuasan Kerja Pegawai serta Dampaknya pada Kinerja Perusahaan (Studi kasus pada PT. Pei Hai International Wiratama Indonesia)" Pasca Sarjana Universitas 17 Agustus Surabaya Jurnal Manajemen Dan Kewirausahaan, Vol 10, No 2, SEPTEMBER 2008: hal.124-135

Chaudhary, R., Rangnekar, S., \& Barua, M. K. (2012). Relationships between occupational self efficacy, human resource development climate, and work engagement. Team Performance Management, Vol 18, pp. 370-383.

Collie, Rebecca J., Jennifer D Shapka, Nancy E Perry. (2012), “School Climate and SocialEmotional Learning Predicting Teacher Stress, Job Satisfaction, and Teaching Efficacy. Journal of Educational Psychology". American Psychological Association, Vol II. No1.

Dawson, B. (2005), "Motivation leaders to better results". Journal of Rubber and Plastics, Vol 37, pp. $11-15$.

Dhermawan, A.A.N,\& I Gede A. S. (2012), “Pengaruh Motivasi, Lingkungan Kerja, Kompetensi dan Kompensasi terhadap Kepuasan Kerja dan Kinerja Pegawai di Lingkungan Kantor Dinas Pekerjaan Umum Provinsi Bali". Journal Manajemen, Strategi Bisins dan Kewira Usaha. Vol. 6, No 2, pp. 174-184.

Juniantara, I.W (2015) “Pengaruh Motivasi dan Kepuasan Kerja terhadap Kinerja karyawan Koperasi di Denpasar. Tesis Universitas Udayana Denpasar.Denpasar.

Fathoni Abdurahmat. (2006), Manajemen Sumber Daya Manusia, Bandung. Rineka Cipta.

Gagne M, Forest.J. (2008)." The Motivation At Work Scale: Validation Evidence In Two Languages". Educational and Psychological Measurement 70 (4) 628-646.

Gary, Dessler. 2010. Manjemen Sumber Daya Manusia. edisi ke-10 jilid 1. Jakarta Barat. PT Indeks.

Gathungu, James, Hannah Wachira W. (2013) . Job Satisfaction Factors that Influence the Performance of Secondary School Principals in their Administrative Functions in Mombasa District, Kenya. International Journal of Education and Research. Vol. 1 No 2, pp. 257-270.

Gibson, L.J., Ivancevich, J.M., \& Donelly, J.H. (2008), Prilaku Organisasi, Struktur. Proses, Binarupa Aksara, Tangerang.

Ghozali, I. (2014). Structural Equation Modelling, Metode Alternatif dengan Partial Least Square (PLS), Edisi 4. Semarang: Badan Penerbit Universitas Diponegoro.

Ghozali, I. (2015). Partial Least Square Konsep,Teknik dan Aplikasi Menggunakan Program SmartPLS 3.0 Untuk Peneliti Empiris, Edisi 2. Semarang: Badan Penerbit Universitas Diponegoro. 


\section{TMM JURNAL MAGISTER MANAJEMEN UNIVERSITAS MATARAM UNRAM \\ VOL. 5 No. 4 NOVEMBER 2016}

Gomes, Faustino Cardoso. (2003). Manajemen Sumber Daya Manusia, Bandung: Remaja Rosdakarya

Hasibuan, \& Malayu S. P (2008), Manajemen Sumber Daya Manusia, Jakarta: PT. Bumi Aksara.

Herzberg, F. (1966), Work and the nature of man. Cleveland, OH: World Publishing Company. Isyandi, B. (2004), Manajemen Sumberdaya Manusia Dalam Perspektif Global.Pekanbaru,Unri Press.

Kadrin, Hasibuan, \& Malayu, S.P., (2009), Manajemen Sumber Daya Manusia, Edisi Revisi, Bumi Aksara, Jakarta : MM-UNRAM.

Lumantow, R.Y, Tewal, Lengkong, V.P.K.,(2015), “Pengaruh Motivasi dan Kepuasan Kerja Terhadap Kinerja Karyawan Dimoderasi Oleh Masa Kerja Pada PT. Deho Canning Company Bitung", Jurnal EMBA, Vol.3,No.1, pp717-725.

Maharjan, Sarita. (2012), "Association between Work Motivation and Job Satisfaction of College Teachers Administrative and Management Review Vol. 24, No 2, pp..45-55.

Mahesa, D. 2010. An alisis Pen gar uh Motivasi dan Kepuasan Kerja terhadap Kinerja Karyawan Dengan Lama Kerja Sebagai Variabel Moderating. Skripsi Fakultas Ekonomi Universitas Diponegoro. Semarang.

Mangkunegara, A.A.A.P. (2008), Manaemen Sumber Daya Manusia Perusahaan, Bandung: PT,Remaa Rosdakarya Offset.

Martins, Helena. Proenca Teresa. (2012). "Minnesota Satisfaction Questionnaire- Psychometric Properties and Validation in a Population of Portuguese Hospital Workers". Escola Superior de Tecnologia da Saúde do Porto, Instituto Politécnico do Porto (STSP), Polytechnic Institute of Porto. CEF.UP, Faculdade de Economia do Porto (FEP), University of Porto.pp.1-20

Mastika W. (2010), “Analisa Faktor-faktor yang membentuk kepuasan kerja penyuluh pada Badan Pelaksana Penyuluh dan Ketahanan Pangan Kabupaten Sumbawa Barat", Tesis Pasca Sarjana Universitas Mataram.

Misail P. (2012). “Remunerasi, Motivasi, Dan Kepuasan Kerja Terhadap Kinerja Pegawai Pada Kantor Pajak". Jurnal Analisis, Vol.1 No.1 : 73 - 78 , ISSN 2303-1001.

Muogbo, U.S. (2013), “The Impact of Employee Motivation On Organisational Performance (A Study Of Some Selected Firms In Anambra State Nigeria)". The International Journal Of Engineering And Science (IJES), ISSN(e): 2319 - 1813 ISSN(p): 2319 - 1805 Volume 2 Issue7 Pages 70-80.

Noermijati, (2008), “Kajian Terhadap Teori Dua-Faktor Herzberg, Pengaruhnya Terhadap Kepuasan Kerja Dan Kinerja Spiritual Manajer Operasional Pada Perusahaan Kecil Rokok Skt di Kota dan Kabupaten Malang. National". Conference on Management Research ISBN: 979-442-242-8.

Noermijati. (2010). Jurnal Aplikasi Manajemen Volume 8 Nomor 1 Februari 2010 (Kajian Deskriptif Tentang Kondisi Faktor Intrinsik dan Ekstrinsik serta Kepuasan Kerja Manajer Menengah-Bawah). Malang: Penerbit Percetakan (UM Press).

Nafrizal, A. Rahman. L, Sofyan. I, (2012), “Pengaruh Insentif, Motivasi Kerja, Gaya Kepemimpinan dan Budaya Organisasi Terhadap Kepuasan Kerja Serta Dampaknya Pada Kinerja Personil Polri Pada Satuan Kerja Biro Operasi Mapolda Aceh". Magister Manajemen Program Pascasarjana Universitas Syiah Kuala Banda Aceh ISSN 23020199 pp. 52- 67. 


\section{IMM JURNAL MAgISTER MANAJEMEN UNIVERSITAS MATARAM

Obimpeh, Mary Owusu, (2014), "Gender and Age Differences in Job Satisfaction Among Junior and Senior Staff in the University of Cape Coast, Ghana, European Journal of Business and Management", Vol. 6, No. 14, p. 91 - 104.

Octaviana, N. (2011). Pengaruh Budaya Organisasi terhadap Motivasi dan Kepuasan Kerja serta Kinerja Karyawan. Skripsi Fakultas Ekonomi UPN Veteran. Yogyakarta.

Purnomowati, E. (2006). Analisis Pengaruh Motivasi terhadap Kepuasan Kerja dan Kinerja Karyawan dengan Variabel Moderator Komitmen pada Perusahaan Garmen di Surabaya. Jurnal Fakultas Ekonomi Uni- versitas Airlangga. Surabaya.

Tahun (2011), Peraturan Pemerintah Nomor 46 Tentang Penilaian Prestasi Kerja Pegawai Negeri Sipil.

Tahun (2013), Peraturan Kepala Badan Kepegawaian Negara No 1 Tentang Ketentuan Pelaksanaan Peraturan Pemerintah Nomor 46 Tahun 2011 Tentang Penilaian Prestasi Kerja Pegawai Negeri Sipil.

Pasolong. H(2010). Teori Administrasi Publik. Alfabeta.

Perda No 4 Tahun 2008 tentang Struktur Organisasi Perangkat Daerah

Prijodarmi Purnomowati, E. (2006). Analisis Pengaruh Motivasi terhadap Kepuasan Kerja dan Produktivitas Karyawan dengan Variabel Moderator Komitmen pada Perusahaan Garmen di Surabaya. Jurnal Fakultas Ekonomi Uni- versitas Airlangga. Surabaya.nto, Soegeng (1994), Disiplin Kiat Menuju Sukses, Jakarta : Pradnya Paramita.

Robbins, Stephen P.-Timothy A. Judge. (2008), Perilaku Organisasi. Edisi 2- Buku 1. Jakarta. Salemba Empat.

Robert L. Mathis dan Jhon. H. Jakson. (2001), Manajemen Sumber Daya Manusia. Buku 1. Jakarta.Salemba Empat.

Ruvandi R (2005), “Imbalan dan gaya kepemimpinan pengaruhnya terhadap kepuasan kerja karyawan di balai besar industry hasil pertanian bogor". Jurnal ilmiah binaniaga, Vol.

1, No. 1, pp 17-25.

Siagian S. (2006). Sistem Informasi Manajemen. Jakarta : Bumi Aksara

Sedarmayanti. (2007), Manajemen Sumber Daya Manusia Reformasi Birokrasi dan Manajemen Pegawai Negeri Sipil, Cetakan Pertama, PT. Refika Aditama, Bandung

Sidik Priadana, et al. (2013), Pengaruh Kemampuan Kerja Dan Motivasi Terhadap Kepuasan

Kerja Serta Implikasinya Pada Produktivitas Pegawai Dinas Pertambangan Dan

Energi Provinsi Jawa Barat Jurnal Ekonomi, Bisnis \& Entrepreneurship Vol. 7, No. 2, Oktober 2013, 52-63. ISSN 2443-0633.

Siregar, N.Y, Herlina., (2014), "Mengukur Empowerment, Self Efficacy Dan Budaya Organisasi Terhadap Kepuasan Kerja Untuk Meningkatkan Kinerja Perguruan Tinggi Swasta Di Bandar Lampung", Proseding Seminar Bisnis \& Teknologi.Vol.15.No16, pp.228-248.

Sugiyono, S (2013), Metode Penelitian Manajemen,Edisi Pertama, Alfabeta, Bandung.

Setyanto, A., Suharnomo, \& Sugiono. (2013). Analisis Pengaruh Kepuasan Kerja dan Iklim Organisasi tehadap Keinginan Keluar (Intention To Quit) dengan Komitmen Organisasi sebagai Variabel Intervening (Pada Perusahaan Perkebunan Kelapa Sawit TELADAN PRIMA GROUP). Jurnal Studi Manajemen \& Organisasi, Volume 10 Nomor 1, Hal. 75 - 81.

Siagian, S.P., (1995). Teori Motivasi dan Aplikasinya, Jakarta : Bina Cipta.

Suarnigsih, N.L.P., Alamsyah, A., Thoyib, A. (2013). Pengaruh Iklim Organisasi terhadap Komitmen Organisasi dan Produktivitas Karyawan di Rumah Sakit. Tesis Program Studi Megister Manajemen Fakultas Kedokteran Universitas Brawijaya. 


\section{TMM JURNAL MAGISTER MANAJEMEN UNIVERSITAS MATARAM

Supranto, J (2004), Analisa Multivarian Arti dan Interprestasi, Jilid I, BPFE, Yogyakarta

Susan Were M. R .W Gakure. E. K Kiraithe. A.G Waititu. (2012), “ Influence of Motivation on Performance in the Public Security Sector with a Focus to the Police Force in Nairobi", Kenya International Journal of Business and Social Science Vol. 3 No 23; pp. 195-204.

Teck Hong, Tan, Amna Waheed. (2011), “Herzberg's Motivation-Hygiene Theory And Job Satisfaction In The Malaysian Retail Sector: The Mediating Effect of Love of Money". Sunway University, School of Business.5, Jalan Universiti, Bandar Sunway 46150 Petaling Jaya. Selangor, Malaysia. Asian Academy of Management Journal, Vol. 16, No 1, pp. $73-94$.

Umar, H. (2008), Metode Penelitian Untuk Skripsi Dan Tesis Bisnis, Raja Press, Jakarta.

Undang-Undang Nomor 32 Tahun 2004 tentang Pemerintahan Daerah.

Undang-Undang Nomor 23 Tahun 2014 perubahan Undang-Undang Nomor 32 Tahun 2004 tentang Pemerintahan Daerah

Widyastuti, Endang, N. (2004). Analisis Pengaruh Iklim Organisasi dan Motivasi Terhadap Produktivitas Pegawai Melalui Variabel Intervening Kepuasan Kerja. Tesis Magister Manajemen Universitas Diponegoro. Semarang.

Veithzal Rivai. (2004). Manajemen Sumber Daya Manusia Untuk Perusahaan. Cetakan Pertama. PT. Raja Grafindo. Jakarta.

Zulhana. (2012), "Faktor-Faktor Yang Membentuk Kepuasan Kerja Bidan di Kabupaten Lombok Barat", tesis Universitas Mataram. Mataram. 